\title{
Teaching of health-related physical activity in medical schools: the Brazilian scenario
}

\section{Ensino de atividade física relacionada à saúde nos cursos de medicina: $\mathrm{O}$ cenário brasileiro}

\section{AUTHOR'S \\ Adriana Akemi Takahashi Dourado ${ }^{1}$ (D) Pedro Curi Hallal ${ }^{1,2}$ (D) \\ Marlos Rodrigues Domingues ${ }^{1}$ (D) \\ Fernando Vinholes Siqueira ${ }^{1}$ (D) \\ 1 Programa de Pós-graduação em Educação Física. Universidade Federal de Pelotas, Pelotas, Rio Grande do Sul, Brasil. \\ 2 Programa de Pós-graduação em Epidemiologia. Universidade Federal de Pelotas, Pelotas, Rio Grande do Sul, Brasil.}

\section{CORRESPONDING}

Adriana Akemi Takahashi Dourado aakemi@gmail.com

Federal University of Pelotas/School of Physical Education, Rua Luiz de Camões, 625.

Pelotas, Rio Grande do Sul, Brazil.

ZIP code: 96055-630.

DOI

$10.12820 /$ rbafs. $24 \mathrm{e} 0096$

\section{(cc) BY-NC-SA}

This work is licensed under the Creative Commons Attribution-NonCommercial-ShareAlike 4.0 International License

\begin{abstract}
Physical activity engagement is a key strategy to improve population health and quality of life. However, studies show that physical activity counseling by physicians is low, and one of the main barriers reported is lack of specific knowledge. The aim of this study is to describe the existence of health-related physical activity content in the curricula of Brazilian Medicine undergraduate courses. A census-type descriptive study was carried out. Online documentation available in institutional websites of all Brazilian Medicine courses curricula were assessed and, when not available, faculty members were contacted. In 2015 we identified 233 medicine courses in Brazil, using data from the Brazilian Ministry of Education. We assessed the documentation in detail of 158 courses (67.8\%). We observed that only $12 \%$ of curricula presented health-related physical activity and/or physical exercise contents. This proportion was higher in public Medical schools compared to private ones $(21.5 \%$ vs. $5.4 \% ; \mathrm{p}=0.002)$. Teaching of health-related physical activity in Brazilian Medicine courses is scarce. We highlight the need for adjustment of curricula considering the well-established benefits of physical activity for public health.
\end{abstract}

Keywords: Motor activity; Medical education; Curriculum; Counseling; Health promotion.

RESUMO

A prática de atividade física é uma estratégia fundamental para melhorar a saúde e a qualidade de vida populacional. No entanto, estudos mostram que o aconselhamento de atividade física por parte dos médicos é baixo e uma das principais barreiras relatadas é a falta de conhecimento específico. O objetivo deste estudo é descrever a existência de conteúdo de atividade física relacionada à saúde nos currículos dos cursos de graduação em Medicina no Brasil. Foi realizado um estudo descritivo do tipo censo, avaliando a documentação on-line disponivel em sites institucionais de todos os currículos dos cursos de Medicina do país e quando esta documentação não estava disponivel, foi feito contato com os coordenadores. Em 2015 foram identificados 233 cursos de medicina no Brasil, utilizando dados do Ministério da Educação do Brasil. Em 158 cursos $(67,8 \%)$ foi possivel avaliar a documentação em detalhes. Observamos que apenas 12\% dos currículos apresentavam em seus curriculos/disciplinas conteúdo sobre atividade física elou exercício físico relacionado à saúde. Essa proporção foi maior nas instituições públicas em comparação às escolas particulares de Medicina (21,5\% vs. 5,4\%; $p=0,002)$. O ensino de atividade física relacionada à saúde nos cursos de Medicina no Brasil é escasso. Destacamos a necessidade de ajuste curricular considerando os benefícios conbecidos da atividade física para a saúde puiblica.

Palavras-chave: Atividade motora; Educação médica; Currículo; Aconselhamento; Promoção da saúde.

\section{Introduction}

Based on the widespread knowledge about the importance of physical activity to improve health through preventing and treating chronic diseases ${ }^{1}$, its inclusion in the public health system is necessary, especially in primary health care ${ }^{2,3}$.

Initiatives to encourage population adherence to active lifestyles are being implemented in many countries $^{4-6}$. A well-known worldwide action is Exercise is Medicine, which suggests the inclusion of physical activity as a key topic to be investigated and followed by health professionals during patient's treatment and consultations ${ }^{7}$.
In Brazil, the Unified Health System (SUS - Sistema Único de Saúde), through the Ministry of Health, promotes strategies to increase physical activity since $2005^{8,9}$. The SUS's main aim is to provide free and universal medical services for the population, and health care is delivered to communities at the Primary Health Care Units $(\mathrm{PHCU})^{10}$. All PHCU's have physicians and, therefore, doctors are in contact with people from different social backgrounds ${ }^{10}$. However, counseling to physical activity engagement by health professionals is still low in Brazil ${ }^{11}$. International evidence shows that medical counseling is highly associated with personal 
knowledge and lifestyle, more specifically, physicians' engagement in physical activity ${ }^{12,13,2,14}$. Studies also report that the ideal timing to increase the knowledge about physical activity benefits among physicians is during undergraduate years ${ }^{15,18}$.

There are few evaluations on the presence of health-related physical activity in Medical schools curricula $^{19}$. An American study reports ${ }^{18}$ that, from 102 medicine schools, only $13 \%$ discussed physical activity health benefits topics during undergraduate education. Another study showed that in the United Kingdom, $56 \%$ of courses taught the current physical activity and health guidelines to their students ${ }^{20}$. Apparently, this knowledge is not discussed satisfactorily among undergraduate students, but no information is available from low and middle-income countries ${ }^{18,20}$. The aim of the present study is to describe the presence of health-related physical activity content in the curriculum of Brazilian Medicine courses and to evaluate if the characteristics of each institution are associated with this outcome.

\section{Methods}

A census-type descriptive study was carried out assessing online documentation available in institutional websites (Ministry of Education and Culture website, besides institutional medicine courses websites and INEP website - National Institute for Educational Studies and Research - http://portal.inep.gov.br/enade/relatorios) to investigate information included in curricula of medicine courses.

First, all Brazilian medicine courses running in 2015 were tabulated based on the Ministry of Education and Culture - MEC (e-mec, available at: http://emec.mec. gov.br). All institutions retrieved were included in the study and their institutional websites were listed. For those with more than one Medicine course (different campuses), both courses were individually considered.

After tabulating all courses, the electronic addresses (institutional websites) were searched for curriculum information. After finding the curriculum, besides collecting generic course and institutional information, a specific search on the content of the outcomes (physical activity and/or physical exercise) was performed using a standardized online form (Google Docs Checklist). First the name of the disciplines was read and, when there was any suggestion that the discipline could mention health-related physical exercise/activity, the content of the discipline was reviewed. Besides, when the information was not available online, a contact was made with coordinator of the course to arrange a phone interview when the checklist was administered. During 2015, data were organized in a spreadsheet (MS Ex$\mathrm{cel}^{\circledR}$ ) including the following information of the institutions or courses: name; type (private, public Federal, public State, public Municipal); address; website; contacts; establishment year of the medicine course (categorized in: before 1970, 1971-2004, and after 2005); presence of physical education course in the Institution (yes/no); presence of specific outcome terms ("physical activity"; "physical exercise") in curricula, categorized later in 'present in mandatory' or 'present in optional' disciplines; and information about the coordination of the course in the website (name and contact); INEP/ Enade score (1-5, later categorized in 1-2 and 3-5). The score is a national evaluation of students who are about to graduate, to test specific knowledge on topics considered essential for future professionals. The assessment is not mandatory for the institutions, therefore not all universities present such score.

The study outcome was based on the presence/absence of content including the terms "Physical activity" or "Physical exercise", collected as a dichotomous variable (yes/no) and was considered positive when at least one of these terms was found in the curriculum of any discipline (optional or mandatory).

Statistical analysis was done in Stata 12.0 (StataCorp ${ }^{\varpi}$. Descriptive analysis was followed by bivariate analysis (chi-square for heterogeneity and linear trend), to describe the outcome distribution according to covariates categories and to test the association between outcome and independent variables.

The present study was approved by the Ethics Committee of the Superior School of Physical Education of the Federal University of Pelotas (CEP/UFPel) under the number 186.505. The authors report no conflicts of interest.

\section{Results}

We identified 233 medicine courses in 2015, out of which, $58.4 \%(\mathrm{n}=136)$ were private; $25.3 \%(\mathrm{n}=59)$ public federal; $12.9 \%(\mathrm{n}=30)$ public state; and $3.4 \%$ $(\mathrm{n}=8)$ municipal.

Table 1 displays the characteristics of medicine courses studied. With respect to Brazil's regions, 42.1\% of Medicine courses were in the Southeast region; 35\% of courses were established between 2005 and 2015, $68.5 \%$ of institutions in which also had Physical Education undergraduate courses. With regard to the 
Table 1 - Description of Brazilian Medicine courses assessed. Brazil, 2015 ( $\mathrm{n}=233)$.

\begin{tabular}{lc}
\hline Characteristics & $\%(\mathrm{n})$ \\
\hline Country's region & \\
South & $17.2(40)$ \\
Southeast & $42.1(98)$ \\
Mid-west & $8.1(19)$ \\
Northeast & $24.0(56)$ \\
North & $8.6(20)$ \\
Institution type & \\
Public Federal & $25.3(59)$ \\
Public State & $12.9(30)$ \\
Public Municipal & $3.4(8)$ \\
Private & $58.4(136)$ \\
Establishment of the course & \\
Before 1970 & $33.3(40)$ \\
$1971-2004$ & $31.7(38)$ \\
After 2005 & $35.0(42)$ \\
PE course in the institution & \\
Yes & $68.5(159)$ \\
No & $31.5(73)$ \\
Enade score & \\
1 & \\
2 & \\
4 & $6.7(11)$ \\
Course's coordinator information in the website & $15.7(26)$ \\
Yes & $36.4(60)$ \\
Others (dean, pedagogic coordination, etc.) & $28.5(47)$ \\
\hline & $12.7(21)$ \\
\hline & $5.1(12)$ \\
\hline
\end{tabular}

$\mathrm{PE}=$ Physical education Enade $=$ National Exam of Student's Performance.

courses that were not included in the study, $57.3 \%$ were private and considering the country's region $38.6 \%$ were in the Southeast, therefore, we assume that losses were not differential. Among the institutions $(n=165)$ presenting the INEP/Enade score (1-5), mean value for medicine courses was $3.3(\mathrm{SD}=1.1)$, and $12.7 \%$ achieved the highest score (5).

Overall, 158 medicine courses were analyzed ( $67.8 \%$ of the 233 existing in the country). Only $12 \%$ presented in their curricula the terms "physical activity" or "physical exercise", and the term "physical activity" was cited 8 times; while "physical exercise" was cited 15 times. Table 2 shows how these subjects are distributed according to discipline's type (mandatory or optional).

When the association between the outcome and covariates was tested (Table 3), the prevalence of physical activity or physical exercise contents in the public
Table 2 - Characteristics of outcome components according to type of discipline in Brazilian medicine courses, 2015 ( $n=158)$.

\begin{tabular}{lcc}
\hline Curricular content & $\mathrm{n}$ & Prevalence \% (95\%CI) \\
\hline Physical activity & & \\
Mandatory discipline & 4 & $2.5(0.6-6.4)$ \\
Optional discipline & 4 & $2.5(0.6-6.4)$ \\
Physical exercise & & \\
Mandatory discipline & 4 & $2.5(0.6-6.4)$ \\
Optional discipline & 11 & $7.0(3.5-12.1)$ \\
\hline
\end{tabular}

$95 \% \mathrm{CI}=95 \%$ confidence intervals

Table 3 - Presence of Physical Exercise and/or Physical Activity in Brazilian medicine courses curricula according to institutional characteristics. Brazil, 2015 ( $n=158)$.

\begin{tabular}{lcc}
\hline Characteristics & $\begin{array}{c}\text { Prevalence } \\
(95 \% \mathrm{CI})\end{array}$ & $\mathrm{p}$-value \\
\hline Country's region & $6.7(0.8-22.1)$ & $0.552^{\mathrm{a}}$ \\
$\quad$ South & $13.2(6.2-23.6)$ & \\
Southeast & $12.5(1.5-38.3)$ & \\
Center-west & $9.4(2.0-25.0)$ & \\
Northeast & $25.0(5.5-57.2)$ & \\
North & & \\
Institution type & $21.5(12.3-33.5)$ & $0.002^{\mathrm{a}}$ \\
Public & $5.4(1.8-12.1)$ & \\
$\quad$ Private & & $0.206^{\mathrm{b}}$ \\
Establishment of the course & $18.2(7.0-35.4)$ & \\
Before 1970 & $10.7(2.3-28.2)$ & \\
1971 - 2004 & $7.4(0.9-24.3)$ & \\
After 2005 & & $0.750^{\mathrm{a}}$ \\
PE course in the institution & $11.5(6.3-18.9)$ & \\
Yes & $13.3(5.1-26.8)$ & \\
No &
\end{tabular}

$\mathrm{PE}=$ Physical education; $95 \% \mathrm{CI}=95 \%$ confidence intervals $; \mathrm{a}=$ heterogeneity's test; $\mathrm{b}=$ linear trend test.

system was $21.5 \%(95 \% \mathrm{CI}: 12.3-33.5)$, while in the private system only $5.4 \%$ (95\%CI: $1.8-12.1)$ presented the outcome $(p=0.002)$. For the remaining variables assessed we could not observe any association.

\section{Discussion}

We carried out a survey in Brazilian medicine courses curricula to search for information about health-related physical activity and/or physical exercise. Only $12 \%$ of the courses presented such contents. It shows a huge information gap on the doctor's education in a health area that affects all age groups and social strata in our population.

The presence of these contents was more frequent in public institutions. A similar North American study evaluated if mandatory teaching about physical activity was different in public or private medicine courses and 
no differences were observed. However, the number of disciplines related to physical activity was significantly lower in private institutions ${ }^{19}$. Studies from UK and US $^{16,18,20}$ did not focus on such comparison, which impairs a direct comparison with our data.

Our results confirm other evaluations carried out in Brazil showing that public universities rank better on most aspects when compared to private schools. Although with no significance, one result was unexpected, the fact that newer courses presented a smaller prevalence of the outcome compared to older courses (7.4\% vs. $18.2 \%$ ). However, it may be a consequence of the real association between the outcome and the type of the institutions (a confounder, as most public institutions were established before 1980). Also, the existence of Physical Education courses in the University did not change the chance of presenting the outcome, meaning that, even though Physical Education teachers were among the faculty members of the university, it does not seem to influence medicine curriculum.

The interest in the physical activity area began early in the 1970's, when Burke et al. questioned in the title of their paper: "Will physicians of the future be able to prescribe exercise?" 21 . The authors reported that only $16 \%$ of medicine courses discuss physical activity within Preventive Medicine disciplines, which could be better explained considering that, by that time, the amount of evidence on this area was scarce. However, more than 40 years later, the information available in the field of physical activity and population health is well established. Still, the panorama seems unchanged in most countries, regardless of social and economic characteristics ${ }^{16,18,20}$.

Our data is like those reported by Garry et al. ${ }^{18}$, who studied 102 North American universities and found a prevalence of $13 \%$ of contents about the health benefits of physical activity, and, in only half of these courses the disciplines were mandatory. Weiler et al. ${ }^{20}$ studied all medicine schools in the United Kingdom, and observed that $56 \%$ of universities taught about the Chief Medical Officer exercise guidelines; however, the time dedicated to this subject was very low (around 4 hours) and irrelevant when compared to fields such as pharmacology (above 100 hours) or other areas that go beyond 330 hours throughout the course. The authors point out that, with this amount of physical activity information in the curriculum it is not expected that physicians feel comfortable to talk about this theme to their patients. Although there is no formal recommendation about the time that should be dedicated to this specific teach- ing or which topics should be discussed, the presence of this kind of knowledge in many disciplines should be encouraged. Besides, investing time to create a mandatory discipline focused on evidence-based physical activity benefits could also be interesting.

A research ${ }^{19}$ used a methodology similar to ours and included 170 medicine courses from the United States, showing that, more than half is not teaching physical activity in mandatory disciplines. When this kind of subject is discussed, the focus is on exercise physiology and not health aspects, lifestyle, prevention or behavioral counseling. These findings agree with our data since we observed a two-fold higher percentage of the term "physical exercise", compared with "physical activity". As for the type of discipline, in only 6 universities the subject was discussed in mandatory disciplines. Also we must mention that, the subjects on this field are so superficially approached, that we could not distinguish, in any of the institutions, if the contents were about physical activity or exercise, focusing on public health, physical performance or disease prevention.

The knowledge of students on the field is superficial $^{22,15}$, most students recognize generic benefits of physical activity, but few can point out specific aspects, such as recommended levels or different types of activity according to individual goals. Besides, most students ignore that physical inactivity is one of the strongest independent risk factors for global mortality and only half of them feel comfortable to counsel about physical activity ${ }^{17}$. One of the reasons reported for the discomfort in counseling is lack of training during formation years ${ }^{17}$.

In 2004 the IOM (Institute of Medicine) released a report showing that medicine education in the United States was failing to diffuse health-related concepts about lifestyle, such as physical activity, alcohol consumption, drugs and nutrition, despite the burden of disease that these aspects represent ${ }^{23}$. By the end of the 1990's, academic deans affiliated with the Association of American Medical Colleges already pointed out health promotion and disease prevention as the most important curriculum topics for the success of future physicians ${ }^{24}$.

In Brazil, national curriculum guidelines, established by the MEC, highlight that future doctors must learn about "Health promotion and understanding of physiological aspects of health, physical activities, sports and its social relationships with the environment". Also, with respect to the knowledge, skills and specific abilities that physicians must have, the promotion of healthy lifestyles is crucial if they desire to 
enlighten their patients and family about health and disease prevention ${ }^{25}$. Despite these guidelines, Brazilian courses, like in other countries, focus medical teaching entirely on healing and treatment of pre-existent diseases basically with surgeries/medicines, lacking information on Preventive Medicine, which results in long-term improved population quality of life and lower costs for the public health system.

Ángyán ${ }^{14}$, in a brief review about the topic, reports that the traditional curriculum contains information about physical activity and disease prevention, but the subjects are not taught systematically, because the curriculum is outdated. On the other hand, many areas such as imaging, genomics, video-surgery, etc. were included in the modern curriculum to keep up with the medical international market ${ }^{14}$.

Garry et al. ${ }^{18}$ observed that $76 \%$ of North American courses were not even planning on changing their curriculum to include physical activity. Despite that, $61 \%$ of courses' coordinators believe that such knowledge must be discussed during medical formation as only $24 \%$ considered that their students were able to counsel patients about being active.

According to Connaughton et al. ${ }^{16}$, deans and coordinators of North American medicine courses declared that around $10 \%$ of their students were fully capable of discussing and counseling about physical activity and, only $6 \%$ of courses were using information from the American College of Sports Medicine's Guidelines for Exercise Testing and Prescription.

The main role of the physician is not to be responsible for exercise prescription, that is the role of physical education professionals. However, doctors should be able to perform an initial recommendation and the follow-up of their patients' evolution while they are closely monitored by professionals with specific training. Counseling on physical activity is low worldwide ${ }^{26}$, although many physicians recognize its relevance ${ }^{27}$, one of the main barriers for counseling is lack of knowledge ${ }^{28}$.

Although most studies were carried out in England and United States, in countries such as India, Anand et al. evaluated 180 medicine students and found that less than $10 \%$ knew about physical activity guidelines, but more than $95 \%$ knew the generic benefits of physical activity. The authors report that medicine teaching in India focuses on diseases and disease control, with no mention to prevention or health promotion through lifestyle ${ }^{15}$.

The University of South Carolina School of Medicine is one of the institutions incorporating, into the medicine graduation course, information based on the Exercise is Medicine (EIM), enabling students to understand the association between physical exercise/activity and the prevention/treatment of diseases, improving their communication skills to work with lifestyle counseling ${ }^{22}$.

In Brazil, EIM was proposed in 2012, however we did not identify publications on strategies to implement it on academic level, although this was one of the original aims of the Project worldwide ${ }^{29}$.

The main limitation of the present study was the low response rate (information available online), which reduced the sample size in $32.2 \%$, leaving out nearly one third of the Brazilian courses. Such loss was similar to the reported by Cardinal et al. ${ }^{19}$ in a study with the same methodology. We hypothesized that this limitation may have overestimated our outcome because the courses that are less updated or less organized may ignore contents about lifestyle or other subjects that do not belong to the traditional physician practice. Another potential limitation is that content available online may not represent the reality in the classroom. But, considering that most teachers in the faculty are doctors and physical activity is not usually included in the clinical settings, we do not expect that health-related physical activity topics are being included by the teacher's own initiative, without the inclusion of such subjects in the official curriculum.

Most Brazilian medicine courses (88\%) do not present health-related physical activity/exercise contents in their curricula. We highlight that such subjects are more likely to be discussed in public institutions. There is a need for evaluation by medicine courses administration on the updating of their curricula facing new and relevant themes, such as the importance of physical activity on individual and population level, as physicians hold the professional role in counseling and promoting behavioral changes towards an active lifestyle.

\section{Conflict of interests}

The authors declare no conflict of interest

\section{Acknowledgments}

During the research the first author received a scholarship from the Coordination for the Improvement of Higher Education Personnel (CAPES).

\section{Authors' contributions:}

Dourado AAT, conducted data collection, planning of the study and wrote the manuscript. Hallal PC, planned the study and revie- 
wed the final version of the text. Domingues MR, conducted the statistical analysis and reviewed the final version of the text. Siqueira FV, planned the study and reviewed the final version of the text.

\section{References}

1. Lee IM, Shiroma EJ,Lobelo F,Puska P, Blair SN, Katzmarzyk PT. Effect of physical inactivity on major non-communicable diseases worldwide: an analysis of burden of disease and life expectancy. Lancet. 2012;380(9838):219-29.

2. Hebert ET, Caughy MO, Shuval K. Primary care providers' perceptions of physical activity counselling in a clinical setting: a systematic review. Br J Sports Med. 2012;46(9):625-31.

3. Weiler R, Stamatakis E. Physical activity in the UK: a unique crossroad? Br J Sports Med. 2015;44(13):912-4.

4. Heath GW, Parra DC, Sarmiento OL, Andersen LB, Owen N, Goenka S. et al. Evidence-based intervention in physical activity: lessons from around the world. Lancet. 2012;380(9838):272-81.

5. Kohl HW, 3rd, Craig CL, Lambert EV, Inoue S, Alkandari JR, Leetongin $\mathrm{G}$, et al. The pandemic of physical inactivity: global action for public health. Lancet. 2012;380(9838):294-305.

6. Phillips E, Pojednic R, Polak R, Bush J, Trilk J. Including lifestyle medicine in undergraduate medical curricula. Med Educ Online. 2015;20:26150.

7. A.C.S.M. Exercise is Medicine. Physical Activity in Health Care. [quoted in 2015 Jul 21]. Available at: https://www. exerciseismedicine.org/support_page.php/physical-activityin-health-care/.

8. Knuth. AG, Malta. DC, Cruz. DK, Freitas PC, Lopes MP, Fagundes J, et al. The physical activity national network coordinated by the Brazilian Ministry of Health: results and evaluative strategies. Rev Bras Ativ Fís Saúde. 2010;15(4):229-33.

9. Malta DC, Barbosa da Silva J. Policies to promote physical activity in Brazil. Lancet. 2011;380(9838):195-6.

10. Brasil MS. Unidades Básicas de Saúde - UBS. Ministério da Saúde; 2013 [quoted in 2015 Apr 4]. Available at: http:// dados.gov.br/dataset/unidades-basicas-de-saude-ubs.

11. Siqueira FV, Nahas MV, Facchini LA, Silveira DS, Piccini $\mathrm{RX}$, Tomasi E, et al. Aconselhamento para a prática de atividade física como estratégia de educação à saúde. Cad. Saúde Pública. 2009;25(1):203-3.

12. Joy EL, Blair SN, McBride $P$, Sallis R. Physical activity counselling in sports medicine: a call to action. Br J Sports Med. 2013;47(1):49-53.

13. Pipe A. Get active about physical activity. Ask, advise, assist: get your patients moving. Can Fam Physician. 2002;48:1314, 21-13.

14. Angyan L. Promoting physical activity in medical education. Mini-review. Acta Physiol Hung. 2004;91(2):157-66.

15. Anand T, Tanwar S, Kumar R, Meena GS, Ingle GK. Knowledge, attitude, and level of physical activity among medical undergraduate students in Delhi. Indian J Med Sci. 2011;65(4):133-42.
16. Connaughton AV, Weiler RM, Connaughton DP. Graduating medical students' exercise prescription competence as perceived by deans and directors of medical education in the United States: implications for Healthy People 2010. Public Health Rep. 2001;116(3):226-34.

17. Dunlop M, Murray AD. Major limitations in knowledge of physical activity guidelines among UK medical students revealed: implications for the undergraduate medical curriculum. Br J Sports Med. 2013;47(11):718-20.

18. Garry JP, Diamond JJ, Whitley TW. Physical activity curricula in medical schools. Acad Med. 2002;77(8):818-20.

19. Cardinal BJ, Park EA, Kim M, Cardinal MK. If Exercise is Medicine(R), Where is Exercise in Medicine? Review of U.S. Medical Education Curricula for Physical Activity-Related Content. J Phys Act Health. 2015; 12:1336-43.

20. Weiler R, Chew S, Coombs N, Hamer M, Stamatakis E. Physical activity education in the undergraduate curricula of all UK medical schools: are tomorrow's doctors equipped to follow clinical guidelines? $\mathrm{Br} \mathrm{J}$ Sports Med. 2012;46(14):1024-6.

21. Burke EJ, Hultgren PB. Will physicians of the future be able to prescribe exercise? J Med Educ. 1975;50(6):624-6.

22. Trilk JL, Phillips EM. Incorporating 'Exercise is Medicine' into the University of South Carolina School of Medicine Greenville and Greenville Health System. Br J Sports Med. 2014;48(3):165-7.

23. Cuff P, Vanselow N. Improving Medical Education: Enhancing the Behavioral and Social Science Content of Medical School Curricula. Washington, DC: National Academies Press; 2004.

24. Graber DR, Bellack JP, Musham C, O’Neil EH. Academic deans' views on curriculum content in medical schools. Acad Med. 1997;72(10):901-7.

25. MEC. Diretrizes curriculares nacionais do curso de graduação em medicina. Ministério da Educação. [quoted in 2015 Apr 4]. Available at: http://portal.mec.gov.br/cne/arquivos/pdf/ Med.pdf.

26. Glasgow RE, Eakin EG, Fisher EB, Bacak SJ, Brownson RC. Physician advice and support for physical activity: results from a national survey. Am J Prev Med. 2001;21(3):189-96.

27. Vallance JK, Wylie M, MacDonald R. Medical students' selfperceived competence and prescription of patient-centered physical activity. Prev Med. 2009;48(2):164-6.

28. Lianov L, Johnson M. Physician competencies for prescribing lifestyle medicine. Jama. 2010;304(2):202-3.

29. CELAFISCS. Exercício é remédio. [quoted in 2020 Jan 29]. Available at: https://celafiscs.org.br/exercicio-e-remedio/.

Receipt: $14 / 10 / 2019$

Approved: 02/03/2020

Quote this article as:

Dourado AAT, Hallal PC, Domingues MR, Siqueira FV. Teaching of health-related physical activity in medical schools: the Brazilian scenario. Rev Bras Ativ Fis Saúde. 2019;24:e0096. DOI: 10.12820/rbafs.24e0096 